Jurnal Penelitian Pendidikan, Psikologi Dan Kesehatan (J-P3K) 2020, Vol. 1 (No. 2) : 109-118

\title{
Pengaruh Kepuasan Kerja dengan Organizational Citizenship Behavior pada Karyawan RS Pertamina Pangkalan Brandan
}

\section{The Effect of Job Satisfaction with Organizational Citizenship Behavior at Pertamina Hospital EmployeesPangkalan Brandan}

\author{
Doli Maulana Gama Samudera Lubis \\ Fakultas Psikologi Universitas Medan Area
}

Diterima : 14 Juli 2020; Disetujui : 04 Agustus 2020; Dipublish : 29 Agustus 2020

*Corresponding author: E-mail: maulanadoli1994@gmail.com@gmail.com

\begin{abstract}
Abstrak
Penelitian ini bertujuan untuk mengetahui pengaruh variabel kepuasan kerja dan komitmen organisasi dengan organizational citizenship behavior (OCB) di Rumah Sakit Pertamina Pangkalan Brandan. Populasi dalam penelitian ini sebanyak 260 yang diambil dari karyawan yang masih aktif bekerja Rumah Sakit Pertamina Pangkalan Brandan. Penelitian menggunakan pendekatan kuantitatif dan pengambilan sampel dalam penelitian ini dengan teknik purposive sampling berjumlah 100 orang. Instrumen yang digunakan adalah angket kepuasan kerja,dengan organizational citizenship behavior (OCB). Penelitian dianalisis dengan menggunakan uji Analisis Regresi Sederhana. Hasil penelitian menunjukkan bahwa ada hubungan $\mathrm{R}_{\mathrm{x} 1-\mathrm{y}}=0,750$ yang positif dari kepuasan kerja dengan organizational citizenship behavior. Hal ini ditunjukkan dengan thitung $=8,608>t_{\text {tabel }}=1,985$ dan nilai signifikansi sebesar 0,000 < 0,05.Dari hasil tersebut menyatakan bahwa Ada pengaruh yang signifikan anatara kepuasan kerja dengan OCB Pada karyawan Rumah Sakit Pertamina Pangkalan Brandan dengan total sumbangan sebesar tujuh puluh lima persen.Pengaruh tersebut menunjukkan bahwa semangkin tinggi pengaruh kepuasan kerja maka semangkin tinggi pula organizational citizenship behavior pada karyawan RS Pertamina Pangkalan Brandan.
\end{abstract}

Kata kunci : Kepuasan Kerja; Organizational Citizenship Behavior

\begin{abstract}
This study aims to determine the influence of variables of job satisfaction and organizational commitment to organizational citizenship behavior (OCB) at Pertamina Hospital Pangkalan Brandan. The population in this study was 260 taken from employees who were still actively working at Pertamina Hospital in Pangkalan Brandan. The study used a quantitative approach and sampling in this study with a purposive sampling technique totaling 100 people. The instrument used was a questionnaire of job satisfaction, with customer organizational citizenship behavior (OCB) that is valid and reliable. The study was analyzed using the Simple Regression Analysis test. The results showed that:there was a positive correlation between Rx1-y $=0.750$ of job satisfaction and organizational citizenship behavior. This is indicated by $t$ count $=8.608>t$ table $=1.985$ and a significance value of $0.000<0.05$. From these results it states that there is a significant influence between job satisfaction with OCB on Pertamina Pangkalan Brandan Hospital employees with a total contribution of seventy-five percent. The effect shows that the higher the influence of job satisfaction, the higher the organizational citizenship behavior of Pertamina Hospital employees Brandan Base.
\end{abstract}

Keywords: Job Satisfaction;Organizational Citizenship Behavior

Rekomendasimensitasi :

Lubis, D.M.G.S. 2020. Pengaruh Kepuasan Kerja dengan Organizational Citizenship Behavior ada Karyawan RS Pertamina Pangkalan Brandan. Jurnal Penelitian Pendidikan, Psikologi dan Kesehatan (J-P3K), 1(2):109118. 


\section{PENDAHULUAN}

Persaingan dalam era global semakin kompleks, sehingga perusahaan harus memperhatikan pemanfaatan SDA dan SDM karena dapat memberikan keuntungan dan memberikan efisiensi dalam pengelolaan suatu perusahaan, sehingga tujuan perusahaan dapat tercapai.Suatu institusi yang pengelolaannya ditujukan untuk melayani masyarakat adalah Rumah Sakit. Sebagai rumah sakit swasta, Rumah Sakit Pertamina Pangkalan Brandan dapat dikategorikan sebagai organisasi penyedia jasa yang juga mengandalkan kualitas pelayanan jasa yang di berikan kepada masyarakat. Kecepatan pelayanan, keramahan, efektifitas tindakan serta kenyamanan bagi pasien dan pengunjung akan menjadi faktor kunci keberhasilan dalam pengelolaan sebuah rumah sakit.

Peningkatan efektifitas, efisiensi dan kreatifitas ini sangat bergantung pada kesediaan karyawan untuk berkontribusi secara positif dalam menyikapi perubahan (Bogler dan Somech, 2009 dalam hasan Basri 2011). Prilaku untuk bersedia member kontribusi positif pekerja ini diharapkan tidak hanya terbatas dalam kewajiban kerja secara formal.

Fenomena yang ada pada karyawan Rumah Sakit Pertamina Pangkalan Brandan adalah berdasarkan observasi selalu bersedia brkerja extra role,dimana karyawan menunjukkan prilaku inovatif dan spontan diluar deskripsi peran yang di tetapkan untuk mencapai tujuan,antara lain mau bekerjasama dengan rekan kerja,member saran yang konstruktif bagi peningkatan kinerja departemen atau organisasi secara umum, meningkatkan kemampuan pribadi melebihi yang di syaratkan

oleh

organisasi,dan menciptakan iklim yang baik bagi organisasi di

Organizational lingkunganluar Citizenship

Behavior (OCB)merupakan perilaku sukarela dari seorang pekerja untuk mau melakukan tugas atau pekerjaan di luar tanggung jawab atau kewajibannya demi kemajuan atau keuntungan organisasinya (Garay dalam Waspodo, 2012). Artinya, seseorang dengan OCB yang tinggi rela tidak dibayar dalam bentuk uang atau bonus tertentu, namun lebih kepada perilaku sosial dari masing-masing karyawan untuk bekerja melebihi apa yang diharapkan oleh perusahaan, seperti menolong rekan disaat jam istirahat dengan tulus ikhlas (Ahdiyana, 2013)

Organ et al. (2008) mendefinisikan OCB sebagai perilaku individual yang bersifat bebas, dan tidak secara langsung mendapat penghargaan dari sistem imbalan formal, tetapi secara keseluruhan dapat meningkatkan efisiensi dan efektifitas fungsi fungsi organisasi. Perilaku tersebut bersifat bebas dan sukarela, karena perilaku tersebut tidak diharuskan oleh persyaratan peran atau deskripsi jabatan yang secara jelas dituntut berdasarkan kontrak dengan organisasi, melainkan sebagai pilihan personal. Dalam dunia kerja yang dinamis seperti saat ini, di mana tugas semakin sering dikerjakan dalam tim dan membutuhkan fleksibilitas, organisasi membutuhkan karyawan yang memiliki perilaku OCB, seperti membantu individu lain dalam tim, mengajukan diri untuk melakukan pekerjaan ekstra, menghindari konflik dengan rekan kerja, mentaati peraturan, serta mentoleransi terjadinya kerugian dan gangguan terkait pekerjaan 
(Robbins dan Judge, 2008). Organizational Citizenship Behavior (OCB) selain disebut the extra role behaviour (Pearche \& Gregersen, 2011; Wright, 2013) dan merupakan salah satu kategori yang penting bagi efektifitas organisasi. Hal ini dikemukakan pula oleh Katz, (2009) yang mengidentifikasi adanya tiga kategori perilaku pekerja yang penting bagi keefektifan organisasi, yaitu individu harus masuk kedalam dan tinggal dalam suatu organisasi, mereka harus menyelesaikan peran khusus dalam pekerjaan tertentu, mereka harus terikat pada aktifitas yang inovatif dan spontan melebihi persepsi perannya. Kategori terakhir itulah yang yang disebut sebagai Organizational Citizenship Behavior. OCB tidak dapat dilepaskan dari komitmen karyawan terhadap organisasi, karena bagaimanapun prestasi kerja yang melebihi apa yang seharusnya, banyak ditentukan oleh kuat tidaknya komitmen terhadap organisasi (Smith, Organ \& Near, 2008).

Pada hakekatnya setiap pencapaian tujuan perusahaan mengacu pada usaha dan kepuasan kerja untuk meningkatkan kehidupan organisasi atau perusahaan menjadi lebih baik. Handoko (2001) menyatakan kepuasan kerja adalah perasaan puas atau tidaknya karyawan dalam bekerja yang berkaitan dengan pekerjaan mereka dalam suatu perusahaan. Perasaan itu akan timbul dari sikap positif karyawan terhadap pekerjaan yang dialami di lingkungan kerjanya. Penelitian dari Shokrkon dan Naami (2009) dan Chiboiwa et al. (2011) menyatakan kepuasan kerja berpengaruh positif dan signifikan terhadap organizational citizenship behavior (OCB).
Permasalahan yang lainnya adalah berkaitan dengan kepuasan kerja terutama terkait dengan sistem pemberian reward terhadap pencapaian target, yang belum diterapkan secara maksimal. Karyawan yang berprestasi masih sering mengeluh karena bonus yang diterimanya sama dengan karyawan lainnya, pada upaya yang dikeluarkan lebih besar. Situasi ini berpengaruh kepada tingkat kepuasan kerja karyawan, yang selanjutnya akan berdampak pada kepuasan mereka dalam bekerja. Sementara itu permasalahan yang berkaitan dengan OCB diantaranya masih sering adanya karyawan yang terlambat masuk jam kerja, pada saat jam kerja banyak yang bermain telepon, mengobrol dengan karyawan lain, yang semuanya itu tidak berkaitan dengan pekerjaan. Juga masih ada yang merokok pada jam kerja, bahkan bermain games di komputer atau browsing di situs jejaring sosial. Hal tersebut menjadikan masih rendahnya kontribusi peran ektra atau OCB pada diri karyawan terhadapperusahaan.

Menurut Robbins dan Judge (2008), kepuasan kerja merupakan faktor penentu utama dari perilaku OCB. Karyawan yang puas cenderung berbicara secara positif tentang organisasi, membantu individu lain, dan melewati harapan normal dalam pekerjaan mereka.

$$
\text { Hughes et al. }
$$
menyatakan bahwa kepuasan kerja berhubungan dengan Kepuasan kerja. Pekerja yang puas lebih cenderung bertahan bekerja untuk organisasi. Pekerja yang puas juga cenderung terlibat dalam perilaku organisasi yang melampaui deskripsi tugas dan peran mereka, serta membantu mengurangi 
beban kerja dan tingkat stres anggota lain dalam organisasi. Pekerja yang tidak puas cenderung bersikap menentang dalam hubungannya dengan kepemimpinan dan terlibat dalam berbagai perilaku yang kontraproduktif. Ketidakpuasan juga alasan utama seseorang meninggalkan organisasi Selain itu organisasi juga memerlukan pemimpin yang mampu mendorong karyawan dalam meningkatkan kemampuan di bidangnya.

Berdasarkan uraian diatas ada pengaruh kepuasan kerja dengan organization citizenship behavior pada karyawan rumah sakit Pertamina Pangkalan Brandan.

Perilaku Kewargaan Organisasi (PKO) dalam bahasa Inggris disebut Organizational Citizenship Behavior (OCB). Organizational citizenship behavior merupakan perilaku sukarela dari seorang anggota organisasi untuk mau melakukan tugas atau pekerjaan di luar tanggung jawab atau kewajibannya demi kemajuan atau keuntungan organisasinya (Garay, 2009).

Organ (Khairuddin, 2018) menjelaskan bahwa organizational citizenship behavior merupakan bentuk perilaku yang merupakan pilihan dan inisiatif individual, tidak berkaitan dengan sistem reward formal organisasi tetapi secara agregat meningkatkan efektivitas organisasi.

Robbins dan Judge (2013) mengatakan bahwa anggota organisasi yang memiliki organizational citizenship behavioryang baik akan memiliki kinerja yang baik pula. Turnley, dkk (2013) organizational citizenship behavioradalah perilaku karyawan yang bersedia bekerja melebihi peran atau tugas yang diwajibkan dan tidak secara langsung diakui oleh sistem reward.

Organizational citizenship behavior merupakan perilaku sekarela ditempat kerja yang dilaksanakan oleh anggota secara bebas yang diluar persyaratan pekerjaan dan ketentuan organisasi sehingga tidak ada dalam sistem imbalan organisasi yang jika dilaksanakan oleh anggota akan meningkatkan berfungsinya organisasi (Wirawan, 2013).

Organ, dkk (2009) mengemukakan lima aspek organizational citizenship behavior, sebagai berikut :

\section{a. Altruism}

Perilaku anggota dalam menolong rekannya yang mengalami kesulitan dalam situasi yang sedang dihadapi baik mengenai tugas organisasi maupun masalah pribadi.

b. Conscientiousness

Perilaku yang ditunjukkan dengan berusaha melebihi yang diharapkan organisasi. Perilaku sukarela yang bukan merupakan kewajiban atau tugas anggota.

\section{c. Sportmanship}

Perilaku yang memberikan toleransi terhadap keadaan yang kurang ideal dalam organisasi tanpa mengajukan keberatan-keberatan. Seseorang yang mempunyai tingkatan yang tinggi dalam sportmanship akan meningkatkan kepuasan kerja yang positif diantara anggota, anggota akan lebih sopan dan bekerja sama dengan yang lain sehingga akan menciptakan lingkungan kerja yang lebih menyenangkan. 


\section{d.Courtessy}

Menjaga hubungan baik dengan rekannya agar terhindar dari masalah-masalah interpersonal. Seseorang yang memiliki courtessy ini adalah orang yang menghargai dan memperhatikan orang lain.

e. Civic Virtue

Maulana (2012) menyatakan bahwa kepuasan kerja merupakan suatu sikap yang dimiliki individu mengenai pekerjaannya yang didasarkan pada faktor lingkungan kerja seperti gaya kepemiminan, kebijakan dan prosuder, aplikasi kecocokan kerja, kondisi kerja dan tunjangan.

Robbins dan Thimoty

mendefinisikan kepuasan kerja sebagai sikap umum seseorang individu terhadap pekerjaannya, selanjutnya dijelaskan pula bahwa seseorang dengan kepuasan kerja yang tinggi menunjukkan sikap positif terhadap pekerjaan itu, sebaliknya seseorang yang tidak puas dengan pekerja terhadap pekerjaan itu.

Berdasarkan kedua definisi tersebut, maka dapatdisimpulkan bahwa kepuasan kerja merupakan perasaan seseorang terhadappekerjaannya yang didasarkan pada kondisi lingkungan kerja yang dapat ditunjukkan melalui sikapnya terhadap perkerjaan itu. Dengan kepuasan kerja yang tinggi, diharapkan kemampuan karyawan dalam melaksanakan tugasnya juga akan meningkat.

Menurut Gibson, Ivancevich dan Donelly (2009) menjelaskan bahwa ada lima faktor yang mempengaruhi kepuasan kerja, yaitu: a. Gajidan upah yang diterima karyawan dianggap sebagai refleksi cara pandang manajer mengenai kontribusi karyawan terhadap organisasi. uang tidak hanya membantu orang untuk memenuhi kebutuhan dasar, tetapi memberikan kepuasan pada tingkat berikutnya.

b. Pekerjaan yang dilakukan Jenis pekerjaan yang dilakukan dapat merupakan sumber kepuasan. Pekerjaan yang memberikan kepuasan adalah pekerjaan yang menarik dan menantang serta tidak membosankan dan pekerjaan itu dapat memberikan status.

c. Promosi Kesempatan untuk berkembang di organisasi dapat menjadi sumber kepuasan.

d. Supervisor Kemampuan supervisor untuk memberikan bantuan teknis dan dukungan moral dapat meningkatkan kepuasan kerja. Misalnya memberikan karyawan kesempatan berpartisipasi dalam membuat keputusan.

e. Rekan kerja. Rekan kerja dapat memberikan bantuan secara teknis dan dapat mendukung secara sosial akan meningkatkan kepuasan kerja karyawan.

Dari beberapa difinisi yang dikemukakan para ahli tersebut di atas, umumnya dikatakan bahwa kepuasan kerja merupakan tingkat perasaan seseorang terhadap pekerjaannya dengan mempertimbangkan dan menilai segala aspek yang ada di dalam pekerjaannya, sehingga timbul dalam dirinya suatu perasaan senang atau tidak senang 
terhadap situasi kerja dan rekan kerjanya. Apa yang dirasakan oleh individu tersebut bisa positif atau negatif, tergantung dari persepsi terhadap pekerjaan yang digelutinya tersebut.

Kepuasan kerja merupakan suatu keadaan yang penting yang harus dimiliki oleh setiap karyawan yang bekerja, di mana manusia tersebut mampu berinteraksi dengan lingkungan kerjanya, mereka akan bekerja dengan penuh gairah dan bersungguh-sungguh, sehingga tujuan organisasi akan tercapai. Mangkunegara (2009).

Berdasarkan uraian di atas disimpulkan aspek-aspek yang digunakan untuk mengungkap kepuasan kerja di Rumah Sakit Pertamina Pangkalan Brandan yaitu promosi,gaji,rekan kerja dan kondisi kerja yang mendukung.

Tujuan penelitaian ini untuk melihat pengaruh kepuasan kerja dengan organizational citizenship behavior karyawan Rumah Sakit Pertamina Pangkalan Brandan.

\section{METODE PENELITIAN}

Desain penelitian yang dipakai adalah metode penelitian kuantitatif. Metode penelitian kuantitatif menurut Sugiyono (2009) Penelitian ini dilaksanakan pada karyawan Rumah Sakit Pertamina Pangkalan Brandan yang berkantor pusat diJalan Wahidin No 1 Pangkalan Brandan Sumatera Utara. Populasi dalam penelitian ini adalah karyawan Rumah Sakit Pertamina Pangkalan Brandan yang berjumlah 260 orang. Sampel dalam penelitian ini adalah sebagian karyawan Rumah Sakit Pertamina Pangkalan Brandan sebesar
$40 \%$ atau 100 orang. Hal ini diasumsikan telah mewakili dari populasi

\section{HASIL DAN PEMBAHASAN}

Pengambilan sampel dalam penelitian ini menggunakan teknik simple random sampling yang dikemukakan Sugiyono (2009) yaitu setiap anggota dari populasi memiliki kesempatan dan peluang yang sama untuk dipilih sebagai sampel. Berikut hasil analisis data dan hasil perhitungan korelasi sederhana dengan menggunakan spss 17.0 for windows.

Uji Korelasi merupakan salah satu teknik analisis dalam statistik yang digunakan untuk mencari hubungan antara dua variabel atau lebih yang bersifat kuantitatif. Dua variabel dikatakan berkorelasi apabila perubahan pada variabel diikuti pada variabel yang lain dengan arah yang sama atau berlawanan. Pada penelitian ini nilai korelasi atau hubungan dapat disimak pada tabel dibawah.

Tabel 1.Correlations

\begin{tabular}{llll}
\hline & & OCB & $\begin{array}{l}\text { Kepuasan } \\
\text { Kerja }\end{array}$ \\
\hline $\begin{array}{l}\text { Pearson } \\
\text { Correlation }\end{array}$ & OCB & 1.000 & .750 \\
& $\begin{array}{l}\text { Kepuasan } \\
\text { Kerja }\end{array}$ & .750 & 1.000 \\
Sig. & (1- OCB &. & \\
tailed) & Kepuasan & .000 &. \\
& Kerja & & \\
N & OCB & 100 & 100 \\
& Kepuasan & 100 & 100 \\
& Kerja & & \\
\hline
\end{tabular}

Berdasarkan hasil penelitian ini diketahui terdapat Pengaruh yang signifikan antara kepuasan kerja dengan OCB pada 
karyawan RS pertamina Pangkalan Brandan . Hasil ini diketahui dari $r_{x 1-y}=0,75$ dengan $p$ $<0,00$. memiliki hubungan positive dengan OCB pada karyawan Rumah sakit Pertamina Salah satu faktor yang berpengaruh terhadap organizational citizenship behaviour, Sloat (2009) mengemukakan kepuasan kerja dapat jadi penyebab yang kuat untuk berkembangnya organizational citizenship behaviour dalam suatu organisasi. Di dalam kepuasan kerja yang positif, karyawan merasa lebih ingin melakukan pekerjaannya melebihi apa yang telah disyaratkan dalam uraian pekerjaan, dan akan selalu mendukung tujuan organisasi jika mereka diperlakukan oleh para atasan dengan sportif dan dengan penuh kesadaran serta percaya bahwa mereka diperlakukan secara adil oleh organisasinya.

Faktor-faktor yang mempengaruhi organizational citizenship behavior yaitu kepribadian, budaya organisasi, iklim organisasi, kepuasan kerja, komitmen organisasi, kepemimpinantransformasional dan servant leadership, tanggung jawab sosial pegawai, umur pegawai, keterlibatan kerja, kolektivisme, keadilan organisasi (Wirawan, 2013).

Salah satu faktor yang berpengaruh terhadap organizational citizenship behavior yaitu iklim organisasi. Sloat (2009) mengemukakan bahwa iklim organisasi dapat jadi penyebab yang kuat untuk berkembangnya organizational citizenship behaviour dalam suatu organisasi. Di dalam kepuasan kerja yang positif, karyawan merasa lebih ingin melakukan pekerjaannya melebihi apa yang telah disyaratkan dalam uraian pekerjaan, dan akan selalu mendukung tujuan organisasi jika mereka diperlakukan oleh para atasan dengan sportif dan dengan penuh kesadaran serta percaya bahwa mereka diperlakukan secara adil oleh organisasinya.

Robbin \& Judge (2013) mengemukakan organizational citizenship behavior dapat timbul dari berbagai faktor dalam organisasi yaitu karena adanya kepuasan kerja yang tinggi: Kepuasan kerja, ketika karyawan merasakan kepuasan terhadap pekerjaan yang dilakukannya maka anggota/karyawan tersebut akan bekerja secara maksimal dalam menyelesaikan pekerjaannya, bahkan melakukan beberapa hal yang mungkin di luar tugasnya.

Organ (2008) mengkategorikan faktor yang mempengaruhi organizational citizenship behavior terdiri dari perbedaan individu, sikap kerja dan faktor kontekstual, berikut penjelasannya :

a. Perbedaan individu termasuk sifat yang stabil yang dimiliki individu, meliputi: kepribadian (misalnya kesadaran dan keramahan), kemampuan, pengalaman, pelatihan, pengetahuan, ketidak pedulian dengan penghargaan, motivasi, kebutuhan, dan nilai individu.

b. Sikap kerja adalah emosi dan kognisi yang berdasarkan persepsi individu terhadap lingkungan kerja, meliputi: komitmen organisasi, persepsi kepemimpinan dan dukungan organisasi, person organization fit, kepuasan kerja, psychological contract, persepsi keadilan dan keadilan organisasi.

c. Faktor kontekstual adalah pengaruh eksternal yang berasal dari pekerjaan, bekerja kelompok, organisasi atau lingkungan. Variabel kontekstual meliputi: karakteristik tugas, sikap pada pekerjaan, gaya kepemimpinan, karakteristik kelompok, budaya dan iklim 
organisasi, profesionalisme, dan harapan peran sosial.

Berdasarkan uraian di atas, dalam penelitian ini akan diteliti faktor-faktor yang mempengaruhi organizational citizenship behavior pada karyawan Rumah Sakit Pertamina Pangkalan Brandan yaitu kepuasan kerja

Selanjutnya penelitian ini menunjukkan bahwa nilai koofesiensi korelasi kepuasan kerja dengan OCB sebesar 0.750 dengan $p=0.000<0.05$ nilai tersebut menunjukan hubungan yang positive signifikan sebesar 0.750. Artinya, variable OCB dijelaskan oleh variabel kepuasan kerja sebesar 75.0\%.

Kepuasan menurut Winardi (2016) merupakan sebuah kondisi akhir (an and state) yang timbul karena dicapainya tujuan tertentu. Kepuasan kerja merupakan perasaan seseorang pekerja tentang berbagai macam aspek kerangka kerja.. Menurut Locke yang dikutip oleh Harnanik (2009) kepuasan kerja merupakan suatu keadaan emosional yang menyenangkan atau positif yang dihasilkan dari penilaian kerja atau pengalaman kerja seseorang.

Faktor penting bagi kepuasan kerja dapat dilihat dari tiga segi

a. kepuasan pekerjaan yang merupakan respon emosional terhadap situasi kerja;

b. kepuasan pekerjaan yang seringkali ditentukan oleh seberapa baik hasil yang diperoleh dan diharapkan;

c. kepuasan pekerjaan merupakan beberapa sikap yang berhubungan dengan pekerjaan.
Organisasi yang karyawannya mendapatkan kepuasan di tempat kerja maka cenderung lebih efektif daripada organisasi yang karyawannya kurang mendapat kepuasan kerja (Robbins, 2009). Demikian pula dengan pendapat Taylor (2013) yang menyatakan bahwa job satisfaction profesional dipengaruhi oleh banyak faktor sehingga dalam mengukurnya diperlukan dimensi yang cukup kompleks.

Dari beberapa difinisi yang dikemukakan para ahli tersebut di atas, umumnya dikatakan bahwa kepuasan kerja merupakan tingkat perasaan seseorang terhadap pekerjaannya dengan mempertimbangkan dan menilai segala aspek yang ada di dalam pekerjaannya, sehingga timbul dalam dirinya suatu perasaan senang atau tidak senang terhadap situasi kerja dan rekan kerjanya. Apa yang dirasakan oleh individu tersebut bisa positif atau negatif, tergantung dari persepsi terhadap pekerjaan yang digelutinya tersebut.

Kepuasan kerja merupakan suatu keadaan yang penting yang harus dimiliki oleh setiap karyawan yang bekerja, di mana manusia tersebut mampu berinteraksi dengan lingkungan kerjanya, mereka akan bekerja dengan penuh gairah dan bersungguh-sungguh, sehingga tujuan organisasi akan tercapai. (Mangkunegara, 2005).

Berdasarkan uraian di atas disimpulkan aspek-aspek yang digunakan untuk mengungkap kepuasan kerja di Rumah Sakit Pertamina Pangkalan Brandan yaitu promosi,gaji,rekan kerja dan kondisi kerja yang mendukung. 


\section{SIMPULAN}

Berdasarkan pada hasil dan
pembahasan yang telah dibuat maka
dapat disimpulkan Ada pengaruh yang
signifikan anatara kepuasan kerja dengan
OCB Pada karyawan Rumah Sakit Pertamina Pangkalan Brandan dengan total sumbangan sebesar tujuh puluh lima persen.Pengaruh tersebut menunjukkan bahwa semangkin tinggi pengaruh kepuasan kerja maka semangkin tinggi pula organizational citizenship behavior pada karyawan RS Pertamina Pangkalan Brandan.

\section{DAFTAR PUSTAKA}

Ahdiyana, Marita. 2013. Dimensi Organizational Citizenship Behavior (OCB) dalam Kinerja Organisasi, h: 1-10. http://www.google.com. Download tanggal 9 November 2018.

Anshori, M. Isa. 2013. Relasi Komitmen Organisasi dan Kepuasan Kerja terhadap Organizational Citizenship behavior (OCB) (Studi Kasus di Poltekes Surabaya), h:425o.ttp://jurnal.stietotalwin.ac.id.

Download tanggal 9 November 2018.

Azwar, S. 2012. Penyusunan Skala Psikologi Edisi 2. Yogyakarta: Pustaka Pelajar

Azwar, S. 2013 Sikap Manusia. Teori dan Pengukurannya. Edisi Kedua. Yogyakarta: Pustaka Pelajar.

Borman, W.C., Ilgen, D.R., \& Klimoski, R.J. 2003. Handbook of Psychology. Industrial and Organizational Psychology, Volume 12. New Jersey: Jhon Wiley \& Sons Inc.

Brahmana, S.S., \& Sofyandi, H. 2009. Tranformational Leadership and Organizational Citizenship Behavior di Utama. Laporan Penelitian. Universitas Widyatama.

Garay, H.D.V. 2006. Kinerja Extra-Role dan Kebijakan Kompensasi. Jurnal. Yogyakarta: Universitas Gajah Mada

Gibson, J.L., Ivancevich, J.M., Donnelly, J.H., \& Konopaske, R. 2012. Organizations: Behavior, Structure, Processes. Fourteenth Edition. New York: The McGraw-Hill Companies, Inc.

Harnanik, 2009. "Analisa Hubungan Kepuasan dan Kemajuan Karir, Kepuasan Atasan,
Beban Kerja, Kepuasan Atas Supervisi dengan Kepuasan kompensasi. Semarang : universitas Negeri Semarang

Huang, C.C., You, C.S., and Tsai, M.T. 2012. A Multidimensional Analysis Of Ethical Climate, Job Satisfaction, Organizational Commitment, and Organizational Citizenship Behaviors, Nursing Ethics, Vol 19, No 4 .

Khairuddin. 2018. Gambaran Komitmen Organisasi Dan Perilaku Kewargaan Organisasi. Jurnal Pendidikan Ilmu-Ilmu Sosial (JUPIIS). 161-166

Mangkunegara.2005.Prilaku dan Budaya Organisasi.Bandung.PT.Remaja Rosdakarya

Mathis, R.L. \& Jackson, J.H. 2008 Human Resource Management. Twelfth Edition.Unites States of America: Thomson SouthWestern

McKeena, E. 2012. Business Psychology and Organisational Behaviour. Fifth Edition. New York. Psychology Press.

Organ, D. W., Podsakof, P. M., and Mackenzie, S. B. 2009. Organizational citizenship behavior: Its nature, antecedents, and consequences. California: Sage Publication.

Robbins, S.P.2010.OrganizationalBehavior. Concept Controversies Applications, Seventh Edition.

Robbins, S.P. \& Judge, T.A. 2013. Organizational Behavior, Fifteenth Edition. New Jersey: Pearson Education Inc.

Setiawan. D. 2011. PengaruhKeadilan Kompensasi PadaKepuasan Kerja KaryawanBank Perkreditan Rakyat diPropinsi Yogyakarta. MM UMY: Yogyakarta

Schneider, B. Ehrhart, M.G., and Macey, W.H. 2013. Organizational Climate and Culture. An v nual Review. San Diego California. San Diego State University.

Sloat, K. C. 2010. Organizational Citizenship: Does Your Firm Inspire Employeesto be "Good Citizens"?. Profesional Safety.

Subri, M. 2009. Ekonomi Sumber Daya Manusia. Raja Grafindo Persada. Jakarta.

Sugiyono. 2009. Statistik Untuk Penelitian. Bandung: Alfabeta.

Taylor, R. (2013). Kiat-Kiat Pede Untuk Meningkatkan Rasa Percaya Diri. Jakarta: Gramedia Pustaka Utama.

Toulson, P. \& Smith, M. 1994. The Relationship Between Organizational Climate and Employee Perceptions of Personnel Management Practices. Jurnal

Turnley, W.H., Bolino, M.C., Lester, S.W., \& Bloodgood, J.M. 2008. The impact of psychological contract fulfillment on the 
performance of in-role and organizational citizenship behaviors. Journal. USA: Elsevier Science Inc.

Triningsih, E., \& Salmah, W. 200o.Pengaruh Atribut Kepribadian terhadap Organizational Citizenship Behavior.Jurnal Psikologi.

Winardi. 2016.Kepemimpinan dalam Manajemen. Jakarta: PT. Rineka Cipta.

Wirawan. 2013. Kepemimpinan. Jakarta: Rajawali Pers.

Yukl, G. 2010. Leadhership in Organization. Seventh Edition. New Jersey: Pearson Education Inc. 